\title{
Mechanical behaviors of enamel, dentin, and dental restorative materials by Three-point bending test
}

\author{
Keyoung Jin Chun ${ }^{*}$, Choong Yeon $\mathrm{Kim}^{1}$ and Jong Yeop Lee ${ }^{2}$ \\ ${ }^{1}$ Department of Advanced Biomedical Engineering, Korea Institute of Industrial Technology, Korea \\ ${ }^{2}$ Department of Dentistry, Kangbuk Samsung Hospital, Sungkyunkwan University School of Medicine, Korea
}

\begin{abstract}
Enamel functions mechanically to grind food and protect dentin. Dentin absorbs bite forces. Thus, the hardness value and mechanical properties should be prioritized when identifying replacement materials for enamel and dentin, respectively. While the compressive and bending forces that comprise the bite force are known, mechanical properties of teeth due to the bending force during biting are still unclear. The mechanical properties due to the bending force of teeth need to be comparatively analyzed with respect to the mechanical properties that depend on the bending force of dental restorative materials. The aim of the present study is to analyze the mechanical properties of enamel, dentin, and various dental restorative materials by using three-point bending tests. In the present study, dental restorative materials including amalgam, gold alloy, and dental resin had lower hardness values than enamel. Gold alloy had a higher maximum bending force than enamel and dentin. Amalgam, gold alloy, and dental resin had a higher maximum bending deflection than enamel. Gold alloy and dental resin had a higher maximum bending deflection than dentin. It could be concluded that gold alloy simultaneously satisfies the requirements of having a hardness value lower than that of enamel with higher bending forces than those of enamel and dentin. These results should aid dentists in clinical treatment choices and will contribute to the development of dental restorative materials that possess properties most similar to the mechanical properties of enamel and dentin.
\end{abstract}

\section{Introduction}

Teeth are the beginning of the digestive tract, where food is digested by mastication [1,2]. Any remaining food in the oral cavity fuels the growth of bacteria and the subsequent formation of plaque, which can progress to dental caries [3-5]. Most cases of dental caries detrimentally change the function and shape of the enamel and dentin. Dental restorative materials are used to restore the damaged tooth function and shape [6-11].

Various dental restorative materials are used in clinical treatment and reconstruction. Amalgam and dental resin are commonly used to fill cavities in enamel and dentin generated by dental caries [12]. Dental resin, dental ceramic, and zirconia are also used for fabricating aesthetically pleasing dentures [13-15]. In particular, they are used for the inlay procedure, since after filling the damaged area with dental restorative materials they can produce a color that is most similar to the color of natural teeth [16]. Gold alloy, which has the same thermal conductivity as natural teeth, is used in inlay crown and bridge procedures $[13,16]$. When the entire tooth is lost, dental implants constructed of titanium alloy are inserted. Titanium alloy is also used to produce implant abutments, denture frameworks, and implant fixtures [17].

When a bite force is applied to the occlusal area of teeth, the bite force consists of two compressive forces: a longitudinal compressive force applied vertically to the tooth axis and a compressive force from the lingual side. The latter can be replaced by the bending force to the longitudinal tooth axis [18] (Figure 1).

Mechanical properties of teeth due to the bite force have mainly been analyzed by stress-strain curves through compression tests [19]. Results suggest that gold alloy simultaneously satisfies the requirements of having a hardness value lower than that of enamel and mechanical properties similar to or better than those of dentin [20,21]. While the compressive and bending forces that comprise the bite force are known, mechanical properties of teeth due to the bending force during biting are still unclear. This lack of knowledge hinders the development of better dental restorative materials for clinical treatment of enamel and dentin. The mechanical properties due to the bending force of teeth need to be comparatively analyzed with respect to the mechanical properties that depend on the bending force of dental restorative materials. This knowledge will contribute to the development of more improved dental restorative materials. To comparatively analyze the properties of teeth and dental restorative materials, bending tests must be carried out on identically-sized specimens using identical test conditions.

The present comparative study investigated the mechanical performance of dental restorative materials (amalgam, dental ceramic, dental resin, gold alloy, zirconia, and titanium alloy) in comparison with those of dental hard tissues (enamel and dentin) using the threepoint bending test.

\section{Materials and methods}

\section{Specimen preparation}

Teeth extracted from healthy individuals $19.3 \pm 4.1$ years of age

Correspondence to: Keyoung Jin Chun, PhD, Department of Advanced Biomedical Engineering, Korea Institute of Industrial Technology, 35-3, Hongcheon-ri, Ipjang-myeon, Seobuk-gu, Cheonan-si, Chungnam, 331-825, Korea, Tel: +82-41-589-8430; Fax: +82-41-589-8413; E-mail: chun@kitech.re.kr

Key words: enamel, dentin, bending force, bending deflection, hardness

Received: July 01, 2016; Accepted: July 28, 2016; Published: August 01, 2016 


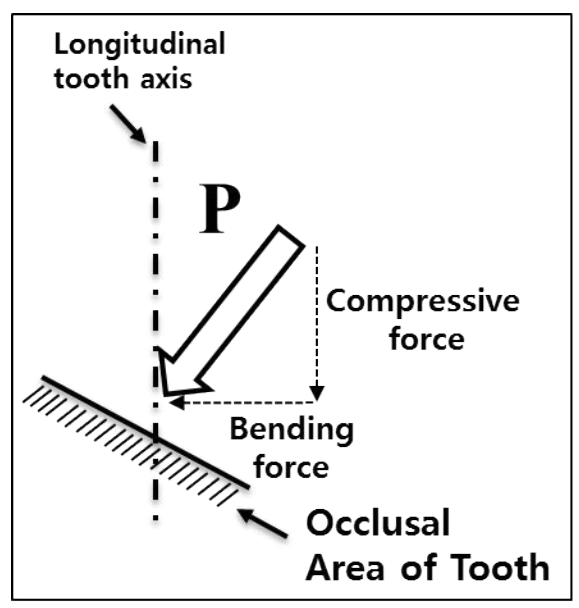

Figure 1. Schematic diagram of compressive and bending force applied on the occlusal area of a tooth.

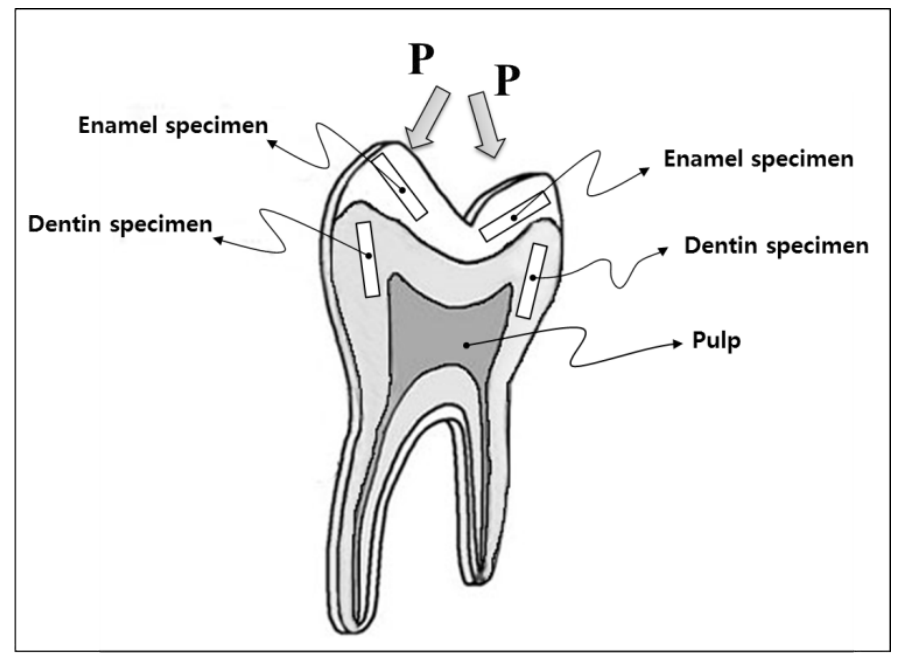

Figure 2. Enamel and dentin specimens from a tooth for bending tests.

were used as dental hard tissue specimens for three-point bending testing (Figure 2). The extracted teeth were cross-sectioned after epoxy resin molding (epoxy resin : epoxy hardener, $40: 10$ ). Cross-sectioned teeth were machine-cut to make 10 enamel specimens and 10 dentin specimens of $6.0 \mathrm{~mm}$ long x $1.0 \mathrm{~mm}$ wide x $1.0 \mathrm{~mm}$ high (Figure 3 ). Cross-sectioning and machine cutting were performed at a feeding speed of $0.2 \mathrm{~mm} / \mathrm{sec}$ and $1000 \mathrm{rpm}$, after installing a model PSI-1405L water-spray cooled carborundum wheel (Eagle Superabrasives, USA) on a model RB216 Culux micro diamond saw machine ( $R \& B$, Korea) capable of cutting at a feeding speed of $0.005-5 \mathrm{~mm} / \mathrm{sec}$ and $200-5000 \mathrm{rpm}$. After polishing with a METPOL2 device (R\&B) using $\# 3000$ wet sanding at $45 \mathrm{rpm}$ with a speed range of $25-300 \mathrm{rpm}$, each specimen was examined to check for the presence of cracks and to identify potential damage at 40x magnification using a model IX71 microscope (Olympus, Japan). No cracks were found in the enamel and dentin specimens. The dental hard tissue specimens were kept in normal saline at room temperature just before testing.

Amalgam (Cavex 68; CAVEX, Netherlands), dental ceramic (Omega 900; Vita, USA), dental gold alloy (Autofluid ${ }^{\circledR}$ 2PF; Metalor, USA), dental resin (Sinfony; 3M, USA), zirconia (Lava ${ }^{\mathrm{mm}}$ Frame Framework Ceramic; 3M), and titanium alloy (Daesung, Korea) were evaluated. Ten specimens $6.0 \mathrm{~mm}$ long x $1.0 \mathrm{~mm}$ wide $\mathrm{x} 1.0 \mathrm{~mm}$ high

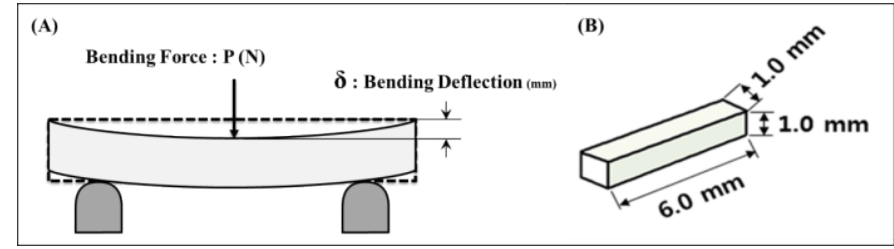

Figure 3. Schematic diagram of (A) three-point bending test and (B) dimension of specimen.

(Figure 3) were made by casting for three-point bending tests for each dental restorative material, except for titanium alloy. Titanium alloy was machine-cut at a feeding speed of $0.2 \mathrm{~mm} / \mathrm{sec}$ and $1000 \mathrm{rpm}$ using RB216 Culux (R\&B) to make 10 specimens of $6.0 \mathrm{~mm}$ in length $x 1.0$ $\mathrm{mm}$ in width $\times 1.0 \mathrm{~mm}$ in height (Figure 3) for three-point bending tests. All the dental restorative materials specimens were sequentially wet-sand polished with \#400, \#1200, and \#3000 polishers (METPOL2; $\mathrm{R} \& \mathrm{~B})$ at $45 \mathrm{rpm}$ to smooth rough surfaces. After polishing, each specimen was visually examined to check for the presence of cracks and identify potential damage that may have occurred during polishing at 40x magnification using an IX71 microscope (Olympus) equipped with a 10x objective lens, and 4x,10x, 20x, and 40x eyepiece lenses. No cracks were found in most of the specimens.

\section{Bending test}

A micro-load system (Universal Testing System; R\&B) with $\pm 0.5 \%$ operating accuracy was used for the three-point bending tests. The volume of the load cell was decided by considering the failure loads of the specimens. A load-cell was installed in the upper part of the jig made for the three-point bending test, and the bending forces during the test were measured. A model UM-K10 98 N load-cell (Dacell, Korea) was used for the amalgam specimens, dental ceramic specimens, and dental resin specimens. A SM603 $980 \mathrm{~N}$ load-cell (MScell, Korea) was used for the gold alloy specimens. A UM-K500 4900 N load-cell (Dacell, Korea) was used for the zirconia and titanium alloy specimens.

For the three-point bending test, a specimen measuring $6.0 \mathrm{~mm}$ in length $\times 1.0 \mathrm{~mm}$ in width $\times 1.0 \mathrm{~mm}$ in height was placed on the twopoint support, with a $4.0 \mathrm{~mm}$ length between the two supports (Figure 3 ). The bending tests for all specimens were done at a loading down speed of $0.1 \mathrm{~mm} / \mathrm{min}$ in a displacement control. A schematic diagram of the bending force $(\mathrm{P})$ and the bending deflection $(\delta)$ by the threepoint bending test is shown in Figure 3. The maximum bending force and deflection are decided as the maximum values just before when the bending force-bending deflection curve is yielding after the increasing region (Figure 4).

\section{Statistical analysis}

To assess the significance of the differences in the maximum bending forces and maximum delfections measured during tests, SPSS (IBM SPSS Software, USA) was used to implement one-way analysis of variance (ANOVA). The significance level was $\mathrm{p}<0.05$.

\section{Results}

\section{Bending test}

Figure 4 shows the typical bending force vs. bending deflection relationship of the dental hard tissue (enamel and dentin) and dental restorative materials (amalgam, dental ceramic, gold alloy, dental resin, zirconia, and titanium alloy). 


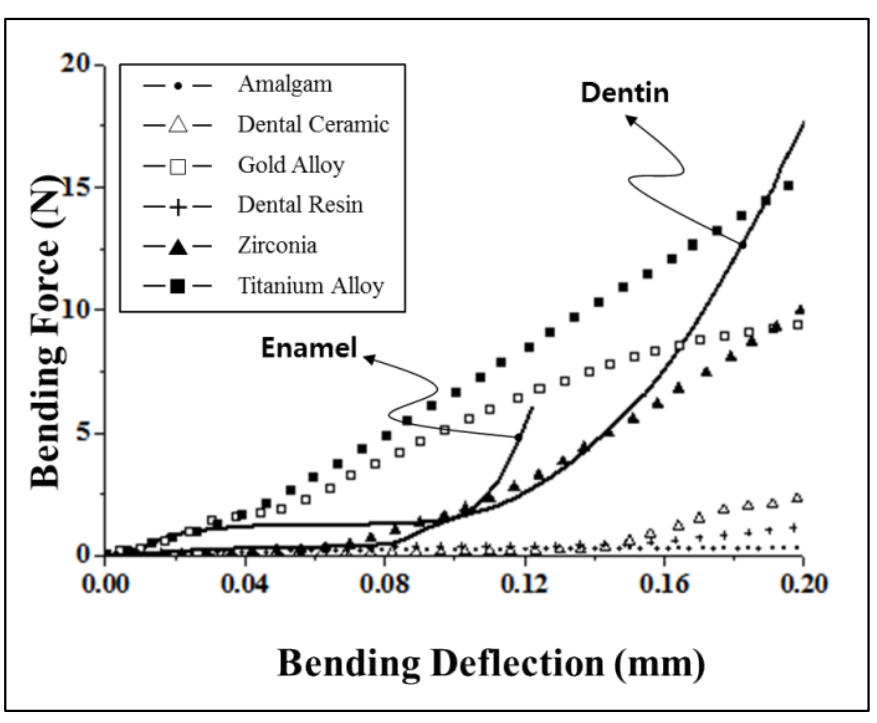

(A)

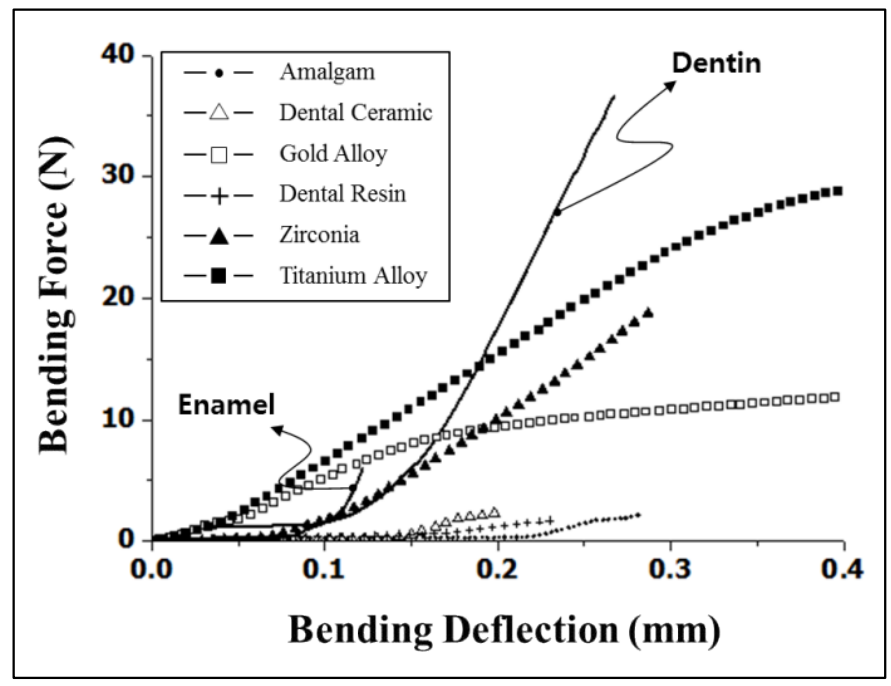

(B)

Figure 4. Typical bending force vs. bending deflection curves of dental hard tissue (enamel, dentin) and dental restorative materials, (A) when bending deflection was up to $0.2 \mathrm{~mm}$, (B) when bending deflection was upto $0.4 \mathrm{~mm}$.

The mean values and standard deviations of the maximum bending force $(\mathrm{N})$ and maximum bending deflection $(\mathrm{mm})$ of each material obtained from the three-point bending tests are shown in Figure 5 and 6 , and Table 1 . The maximum bending forces of enamel and dentin were $6.9 \pm 2.1 \mathrm{~N}$ and $39.7 \pm 8.3 \mathrm{~N}$, respectively, and the maximum bending deflections of enamel and dentin were $0.12 \pm 0.02 \mathrm{~mm}$ and $0.25 \pm 0.03 \mathrm{~mm}$, respectively. The maximum bending force of dentin was about 6 times greater than that of enamel, and the maximum bending deflection of dentin was about twice that of enamel.

The maximum bending force of the amalgam, dental ceramic, gold alloy, dental resin, zirconia, and titanium alloy was $1.9 \pm 0.4 \mathrm{~N}, 2.7 \pm 0.6$ $\mathrm{N}, 66.9 \pm 4.1 \mathrm{~N}, 2.7 \pm 0.3 \mathrm{~N}, 19.0 \pm 2.0 \mathrm{~N}$, and $121.3 \pm 6.8 \mathrm{~N}$, respectively. The maximum bending deflection of the dental restorative materials in the same respective order was $0.20 \pm 0.08 \mathrm{~mm}, 0.28 \pm 0.07 \mathrm{~mm}, 2.53 \pm$ $0.12 \mathrm{~mm}, 0.37 \pm 0.05 \mathrm{~mm}, 0.39 \pm 0.05 \mathrm{~m}$, and $2.80 \pm 0.08 \mathrm{~mm}$.

\section{Discussion and conclusions}

Dental restorative materials with greater maximum bending force than enamel were gold alloy, zirconia, and titanium alloy. Materials with greater maximum bending force than dentin were gold alloy and titanium alloy (Figure 5). There was no significant difference $(p>0.1)$ between the maximum bending forces of dental ceramic and dental resin (Table 1).

All dental restorative materials had greater maximum bending deflection than enamel and all the materials except for amalgam had greater maximum bending deflection than dentin (Figure 6). There was no significant difference between the maximum bending deflections of gold alloy and titanium alloy $(\mathrm{p}>0.1)$.

Enamel functions mechanically to grind (crush) food and protect dentin because of its higher wear resistance. Dentin absorbs bite forces because of its higher force resistance. The hardness value should be prioritized when identifying replacement materials for enamel. In contrast, in evaluating replacement material of dentin, the bending force and bending deflection are paramount.

Dental restorative materials including amalgam, gold alloy, and dental resin displayed lower hardness values than enamel, which is important when considering the wear of the opposing natural teeth (Table 1). Gold alloy had higher maximum bending force than enamel and dentin. Amalgam, gold alloy, and dental resin had higher maximum bending deflection than enamel. Gold alloy and dental resin had higher maximum bending deflection than dentin. The results indicate that gold alloy simultaneously satisfies the requirements of having a hardness value lower than that of enamel and higher bending forces than those of enamel and dentin. Titanium alloy (Ti$6 \mathrm{Al}-4 \mathrm{~V}$ grade 5) is not used as filler for damaged teeth. But, because of its biocompatibility and osseointegration, it is a suitable material for dental implant abutment and fixture. Since the maximum bending

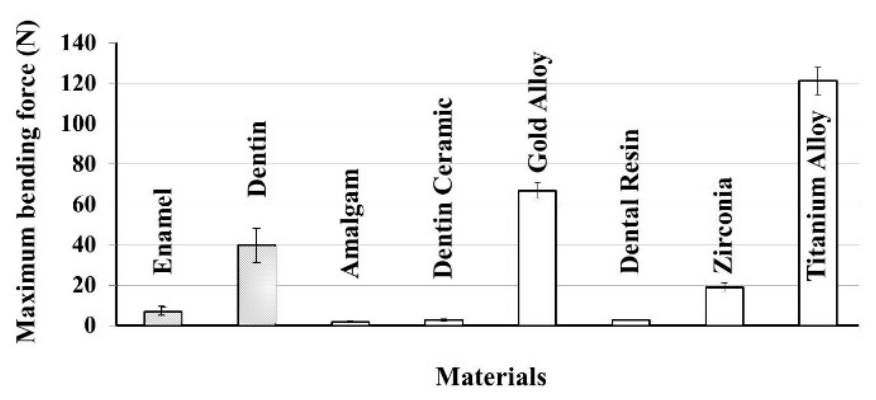

Figure 5. Comparisons of the maximum bending force $(\mathrm{N})$ of each material from threepoint bending tests.

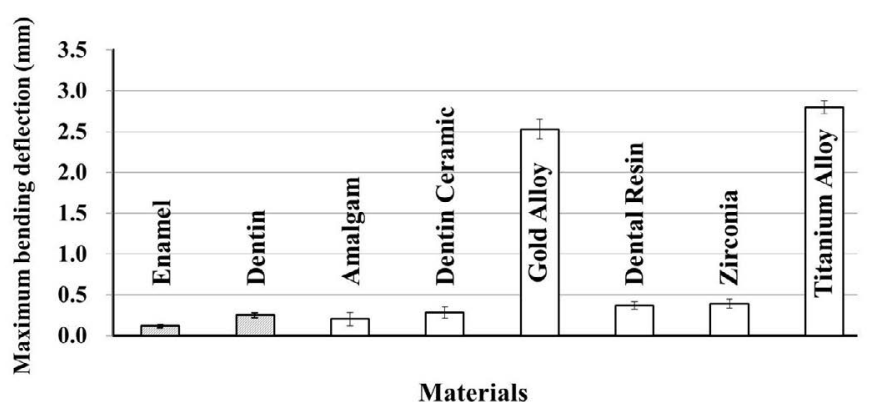

Figure 6. Comparisons of the maximum bending deflection $(\mathrm{mm})$ of each material from three-point bending tests. 
Table 1. Comparison of maximum bending force, deflection and hardness values of dental hard tissues and dental restorative materials $(n=10 /$ material $)$.

\begin{tabular}{|l|c|c|c|}
\hline Materials & $\begin{array}{c}\text { Maximum Bending } \\
\text { Force (N) }\end{array}$ & $\begin{array}{c}\text { Maximum Bending } \\
\text { deflection (mm) }\end{array}$ & $\begin{array}{c}\text { Vikers Hardness Values } \\
\mathbf{( H V )}\end{array}$ \\
\hline Enamel & $6.9 \pm 2.1$ & $0.12 \pm 0.02$ & $274.8 \pm 18.1[24]$ \\
\hline Dentin & $39.7 \pm 8.3$ & $0.25 \pm 0.03$ & $65.6 \pm 3.9[24]$ \\
\hline Amalgam & $1.9 \pm 0.4$ & $0.20 \pm 0.08$ & $90[25]$ \\
\hline Dental Ceramic & $2.7 \pm 0.6 \dagger$ & $0.28 \pm 0.07$ & $420[26]$ \\
\hline Gold Alloy & $66.9 \pm 4.1$ & $2.53 \pm 0.12 *$ & $130 \sim 135[27]$ \\
\hline Dental Resin & $2.7 \pm 0.3 \dagger$ & $0.37 \pm 0.05$ & $86.3 \sim 124.2[28]$ \\
\hline Zirconia & $19.0 \pm 2.0$ & $0.39 \pm 0.05$ & $1250[29]$ \\
\hline Titanium Alloy & $121.3 \pm 6.8$ & $2.80 \pm 0.08^{*}$ & $349[30]$ \\
\hline
\end{tabular}

$\dagger$ No significant difference between dental ceramic and dental resin $(p>0.1)$

* No significant difference between gold alloy and titanium alloy $(p>0.1)$

force and maximum bending deflection of titanium alloy are much higher than those of the enamel and dentin, titanium alloy would be seem to be appropriate as a dental implant. However, the values from bending force and bending deflection of titanium alloy showed marked differences from the results of the three-point bending test of dental hard tissue. Due to the excessive results of titanium alloy, the bite force on the dental implant may result in excessive stress of dental hard tissue and bone. Therefore, development of a new dental implant that does not significantly differ from dental hard tissue and that has good osseointegration, would be helpful for dental patients.

These results are expected to aid dentists in their clinical decisionmaking, and should contribute to the development of a new dental restorative material that is most similar to the mechanical properties of enamel and dentin.

\section{Conflict of interest statement}

There is no conflict of interest regarding this manuscript.

\section{Acknowledgment}

This research was supported by Korea Institute of Industrial Technology (KITECH), Republic of Korea.

\section{References}

1. Nalliah RP, Allareddy V, Elangovan S, Karimbux N, Allareddy V (2010) Hospital based emergency department visits attributed to dental caries in the United States in 2006. $J$ Evid Based Dent Pract 10: 212-222. [Crossref]

2. Haines DJ (1968) Physical properties of human tooth enamel and enamel sheath material under load. J Biomech 1: 117-125. [Crossref]

3. Zero DT, Zandona AF, Vail MM, Spolnik KJ (2011) Dental caries and pulpal disease. Dent Clin North Am 55: 29-46. [Crossref]

4. Xu HH, Smith DT, Jahanmir S, Romberg E, Kelly JR, et al. (1998) Indentation damage and mechanical properties of human enamel and dentin. J Dent Res 77: 472-480. [Crossref]

5. Jantarat J, Palamara JE, Lindner C, Messer HH (2002) Time-dependent properties of human root dentin. Dent Mater 18: 486-493. [Crossref]
6. Tillberg A, Järvholm B, Berglund A (2008) Risks with dental materials. Dent Mater 24: 940-943. [Crossref]

7. Vaderhobli RM (2011) Advances in dental materials. Dent Clin North Am 55: 619-625. [Crossref]

8. Beatty MW1, Pidaparti RM (1993) Elastic and fracture properties of dental direct filling materials. Biomaterials 14: 999-1002. [Crossref]

9. Marshall GW Jr, Balooch M, Gallagher RR, Gansky SA, Marshall SJ (2001) Mechanical properties of the dentinoenamel junction: AFM studies of nanohardness, elastic modulus, and fracture. J Biomed Mater Res 54: 87-95. [Crossref]

10. Arcis RW, Lopez-Macipe A, Toledano M, Osorio E, Rodríguez-Clemente R, et al. (2002) Mechanical properties of visible light-cured resins reinforced with hydroxyapatite for dental restoration. Dent Mater 18: 49-57. [Crossref]

11. Padmanabhan SK, Balakrishnan A, Chu MC, Kim TN, Cho SJ (2010) Microindentation fracture behavior of human enamel. Dent Mater 26: 100-104. [Crossref]

12. Koplin C, Jaeger R, Hahn P (2009) A material model for internal stress of dental composites caused by the curing process. Dent Mater 25: 331-338. [Crossref]

13. De Jager N, de Kler M, van der Zel JM (2006) The influence of different core material on the FEA-determined stress distribution in dental crowns. Dent Mater 22: 234-242. [Crossref]

14. Stober T1, Lutz T, Gilde H, Rammelsberg P (2006) Wear of resin denture teeth by twobody contact. Dent Mater 22: 243-249. [Crossref]

15. Abou Tara M, Eschbach S, Wolfart S, Kern M (2011) Zirconia ceramic inlay-retained fixed dental prostheses - first clinical results with a new design. J Dent 39: 208-211. [Crossref]

16. Knorr SD, Combe EC, Wolff LF, Hodges JS (2005) The surface free energy of dental gold-based materials. Dent Mater 21: 272-277. [Crossref]

17. Javier Gil F, Planell JA, Padrós A, Aparicio C (2007) The effect of shot blasting and heat treatment on the fatigue behavior of titanium for dental implant applications. Dent Mater 23: 486-491. [Crossref]

18. He LH, Swain MV (2007) Nanoindentation derived stress-strain properties of dental materials. Dent Mater 23: 814-821. [Crossref]

19. He LH, Fujisawa N, Swain MV (2006) Elastic modulus and stress-strain response of human enamel by nano-indentation. Biomaterials 27: 4388-4398. [Crossref]

20. Chun K, Choi H1, Lee J2 (2014) Comparison of mechanical property and role between enamel and dentin in the human teeth. $J$ Dent Biomech 5: 1758736014520809. [Crossref]

21. Chun KJ, Lee JY (2014) Comparative study of mechanical properties of denta restorative materials and dental hard tissues in compressive loads. J Dent Biomech 5: 1758736014555246. [Crossref]

22. Davis JR (1990) Metals handbook: properties and selection: nonferrous alloys and special-purpose materials. (10th edn.) Materials Park, OH: ASM International.

23. http://vident.com..27

24. http://www.metalor.com

25. Poskus LT, Placido E, Cardoso PE (2004) Influence of placement techniques on Vicker and Knoop hardness of class II composite resin restorations. Dent Mater 20: 726-732. [Crossref]

26. http://solutions.3m.com/wps/portal/3M/en_US/3M-ESPE-NA/dental-professionals/

27. Boyer R, Welsch G, Collings EW (1994) Materials properties handbook: titanium alloys. Materials Park, OH: ASM International.

Copyright: (C2016 Chun KJ. This is an open-access article distributed under the terms of the Creative Commons Attribution License, which permits unrestricted use, distribution, and reproduction in any medium, provided the original author and source are credited. 